\title{
MERAJUT KEMBALI KOMUNITAS DAMAI: STUDI LANDASAN BIBLIS DAN TEOLOGIS RESOLUSI KONFLIK
}

\author{
Agus Supratikno \\ Fakultas Teologi Universitas Kristen Satya Wacana \\ J1. Diponegoro 52-60. Salatiga. 50711 \\ Email: agus.supratikno@uksw.edu
}

\begin{abstract}
Agus Supratikno, Re-establishing Peaceful Communities: The Study of Biblical and Theological Foundations for Conflict Resolution. Plurality which is considered as a nation's wealth, it also turns out to be the cause of the emergence of conflicts with nuances of ethnicity, race, and religion. Unfortunately, political elites often politicize issues based on ethnic and religious sentiments to gain power. They did not consider the serious effects that were caused as a result of the politicization of ethnic and religious issues. Horizontal conflicts with nuances of religion and ethnicity that have occurred in various regions in Indonesia, such as in Ambon, Poso, Kalimantan, are more often triggered by the politicization of religious and ethnic issues or initially the conflict is not caused by ethnic or religious problems, but often the conflict brought to the realm of religion so as to make the conflict increasingly enlarged and inevitable. This writing is an effort to explore the biblical and theological foundation for an effort to build a peaceful community post the conflict. This study uses hermeneutic studies and the library research methods by utilizing library resources both books and journals related to conflict resolution.
\end{abstract}

Key Words: Biblical Foundation, Theological, Conflict Resolution, Religion, Peaceful Communities,

\begin{abstract}
ABSTRAK: Agus Supratikno, Merajut Kembali Komunitas Damai: Studi Landasan Biblis dan Teologis untuk Resolusi Konflik. Pluralitas yang dianggap sebagai suatu kekayaan bangsa, ternyata juga bisa menjadi penyebab munculnya konflik bernuansa suku, ras dan agama. Sayangnya para elite politikjustru sering mempolitisasi isu-isu berdasarkan sentimen suku dan agama untuk meraih kekuasaan. Mereka tidak mempertimbangkan dampak serius yang ditimbulkan sebagai akibat politisasi isu suku dan agama. Konflik-konflik horizontal bernuansa agama dan suku yang pernah terjadi di berbagai daerah di Indonesia, seperti di Ambon, Poso, Kalimatan, lebih sering dipicu oleh adanya politisasi terhadap isu agama dan suku. Pada awalnya konflik tersebut bukanlah disebabkan oleh masalah agama, tetapi seringkali konflik tersebut dibawa ke ranah agama sehingga menjadikan konflik semakin membesar dan tak terelakkan. Tulisan ini adalah sebuah upaya menggali landasan biblis dan teologis bagi suatu upaya merajut kembali komunitas damai pasca konflik. Penelitian ini menggunakan metode perpaduan antara studi hermeneutik dan literatur dengan memanfaatkan sumber-sumber pustaka baik buku maupun jurnal yang berkaitan dengan topik yang dibahas.
\end{abstract}

Kata Kunci: Landasan Biblis, Teologis, Resolusi Konflik, Agama, Komunitas Damai,

\section{PENDAHULUAN}

Keragaman di Indonesia, belakangan ini menghadapi suatu ancaman yang cukup serius dengan menguatnya politik identitas berdasarkan suku, ras dan agama. Sejauh rekaman konflik keagamaan di Indonesia dilacak, akan terlihat tiga pola besar: konflik antarumat agama yang berbeda, konflik antara satu umat agama dengan kelompok yang dicap sebagai sesat, dan konflik intern-umat satu agama yang memiliki pemahaman berbeda (Muqoyyidin, 2012, p. 315). Para elit politik seringkali secara se- ngaja menggunakan isu suku dan agama sebagai alatuntuk mencapai tujuan politiknya yaitu meraih kursi kekuasaan. Bahkan mempolitisasi isu-isu yang bernuansa SARA untuk menyerang lawan politiknya. Arjon, menjelaskan bangkitnya sentimen agama dan politik identitas di Indonesia mencapai phase kritis. Indonesia bukanlah negara agama juga bukan negara sekuler, meski mengakui keberadaan Allah sebagaimana dalam sila pertama Pancasila. Sebagaimana korupsi, hak asasi manusia agama juga menjadi isu mendasar materi kampanye para politikus. Ti- 
ga hal tersebut di atas merupakan poin utama untuk menarik perhatian pemilih. Tiga hal tersebut di atas meru-pakan poin utama untuk menarik perhatian pemilih. Namun, sejak jatuhnya era Presiden Soeharto dan Orde Baru, sentimen keagamaan tidak pernah digunakan untuk menyerang agama lain sampai di Pemilihan Kepala Daerah DKI Jakarta 2017 (Arjon, 2018, p.171)

Pluralitas yang dianggap sebagai suatu kekayaan bangsa, ternyata juga bisa menjadi penyebab munculnya konflik bernuansa suku, ras dan agama. Para elite politik seringkali tidak mempertimbangkan dampak serius yang sangat mungkin ditimbulkan sebagai akibat politisasi isu-isu SARA secara khusus isu agama. Konflik-konflik horizontal bernuansa agama dan suku yang pernah terjadi di berbagai daerah di Indonesia, seperti di Ambon, Poso, Kalimatan, menjadi semakin membesar ketikaditiupkan isu-isu bernuansa SARA. Jadilah konflik yang awalnya sama sekali bukan bernuansa agama berkembang menjadi konflik yang dimuarakan ke isu agama dan suku. Konflikpun semakin membesar dan semakin sulit dihentikan, lingkaran dendam mendendam terus terjadi dan melahirkan lingkaran kekerasan. Ketika konflik telah masuk ke konflik bernuansa agama, maka peran agama sangat diharapkan dapat memberikan sumbangan bagi terjadinya resolusi konflik. Tulisan ini adalah sebuah upaya menelisik landasan biblis dan teologis Kristen untuk menjadi dasar resolusi konflik, untuk merajut kembali komunitas damai pasca konflik.

\section{METODE}

Kajian ini merupakan kajian perpaduan antara studi hermeneutik dan literatur tentang landasan biblis dan teologis untuk resolusi konflik. Dalam penelitian ini sumber-sumber yang relevan dengan fokus penelitian, baik dari jurnal maupun buku-buku menjadi sumber yang dianalisis dan dicermati keterkaitannya dengan hasil interpretasi terhadap teks-teks baik dalam Perjanjian Lama maupun Perjanjian Baru. Hasil kajian tersebut kemudian menjadi lan- dasan biblis dan teologis bagi praxis Kristen berkaitan dengan resolusi konflik.

\section{HASIL DAN PEMBAHASAN}

\section{Makna Damai Dalam Perjanjian Lama}

Dalam teks Perjanjian Lama (Masoret), kata benda shalom muncul 235 kali (Mauser, 1992, p.13). Dalam The Brown-Driver-Briggs Hebrew and Eng-

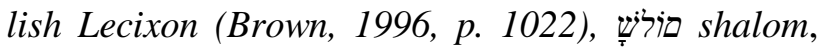
adalah kata benda maskulin, yang artinya sebagai berikut: kesempurnaan, kesehatan, kesejahteraan, dan kedamaian; (1) keutuhan, kesempurnaan dalam hal jumlah; (2) keselamatan, kesehatan, dalam tubuh; (3) kesejahteraan, kesehatan dan kemakmuran; (4) damai, tenang, ketenangan, kepuasan; (5) perdamaian, persahabatan: yang meliputi hubungan dengan sesama manusia; hubungan dengan Allah; damai dari perang. Efan (1950, p.165) menjelaskan bahwa akar kata shalom (sh-l-m) mencakup tiga ide yaitu totalitas, keadaan baik dan harmoni. Sedangkan Kata sifat shalem berarti utuh/keseluruhan. Von Rad (1964) menyatakannya sebagai keadaan baik yang mencakup seluruh aspek kehidupan, bersifat holistik. Jadi kata shalom memiliki berbagai nuansa makna meliputi keadaan material dan fisik, relasi yang baik, sikap moral, keselarasan dan keharmonisan yang dialami oleh manusia dalam keseluruhan dimensi kehidupannya yang meliputi rohani, fisik, intelektual, emosi, sosial dan ekonomi. Sebagaimana ditegaskan Rise (2005, p.11), Shalom sebagai kedamaian Allah menerobos semua dimensi kehidupan manusia, termasuk spiritual, fisik, kognitif, emosional, sosial, dan ekonomi. Shalom mengejar belas kasihan, kebenaran, keadilan, dan kedamaian melalui pertobatan pribadi dalam Kristus dan transformasi sosial. Sedangkan bila dilihat dari sisi relasional kata shalom, mencakup relasi antara manusia dengan Allah (vertikal), manusia dengan sesamanya (horizontal). Konsep shalom juga mencakup keutuhan hubungan dalam hidup sehari-hari, baik hubungan terhadap sesama maupun dengan alam semesta (Dachi 2017, p. 44). 
Penting untuk dipahami bahwa kata shalom memiliki makna yang bersifat aktif, bersifat transformatif. Shalom, bukan bersifat pasif terhadap status quo, tetapi aktif melawan semua bentuk penindasan, eksploitasi dan ketidakadilan hukum. Shalom mentransformasikan situasi-situasi tersebut menuju keadilan. Di dalam konsep shalom, tidak ada lagi kelompok manusia yang ditinggalkan dalam proses rekonsiliasi, apapun suku, agama, ideologi, dan latar belakang afiliasi politiknya.

Implikasi penting bagi gereja adalah gereja harus melawan semua bentuk kekerasan dan penindasan terhadap harkat dan martabat kemanusiaan yang dilakukan baik oleh pribadi maupun kelompok bahkan kekerasan struktural. Rekonsiliasi dalam makna shalom, bukan saja menjangkau pertobatan secara individual tetapi juga transformasi sosial. Mentransformasikan segala bentuk penindasan, eksploitasi, dan ketidakadilan hukum menjadi masyarakat yang damai dan berkeadilan.

\section{Menelisik Makna Damai dalam Perjanjan Baru}

Dalam Perjanjian Baru kata damai berasal dari kata eirene. LXX menggunakan kata eirene sebagai pengganti kata shalom. Dalam Thayer's Greek Lexicon Strongs, 1515 eirhnh (Thayer, 1992, p.182) diartikan sebagai keadaan ketenangan nasional, bebas dari amarah dan perang, damai di antara individuindividu, harmoni, keamanan, keselamatan, kemakmuran, dan kemurnian. Secara khusus merujuk ke-

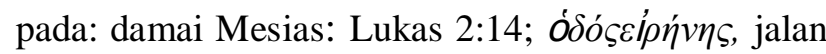

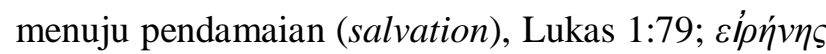

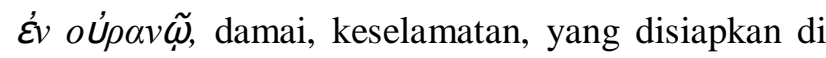

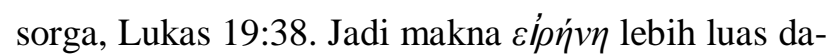
ri sekedar tidak ada perang. Kata eirene memiliki berbagai nuansa makna seperti: selamat (Mrk. 5:34; Luk. 7:50), Damai (Ibr. 12:14), damai sejahtera (Luk. 1:79; 2:14; Yoh. 14:27; 20:19; Kis. 10:36).

Tuhan Yesus sangat menekankan ajaran untuk mengasihi sesama bahkan musuh dan tidak membalas kekerasan dengan kekerasan (non-violence), bahkan non-resistence, "Tetapi Aku berkata kepadamu:
Kasihilah musuhmu dan berdoalah bagi mereka yang menganiaya kamu" (Mat. 5:44). Ajaran Tuhan Yesus dalam ayat ini menunjukan secara tegas bahwa hidup berdamai adalah pokok dari ajaran yang ingin diterapkan Tuhan Yesus. Yesus sangat menekankan bahwa mengupayakan perdamaian jauh lebih penting dibandingkan ritual keagamaan, seperti teks berikut ini "Tinggalkanlah persembahanmu di depan mezbah itu dan pergilah berdamai dahulu dengan saudaramu, lalu kembali untuk mempersembahkan persembahan itu" (Mat. 5:25).

Dalam Perjanjian Baru,Paulus menjelaskan secara luas mengenai konsep pendamaian. Kata mendamaikan, katallassein, terdapat tiga belas kali dalam surat-surat asli Paulus dan pasca Paulus. Penggunaan kata ini mencerminkan suatu pendamaian kembali setelah terjadi perang (Schreiter, 2000, p.46). Hal itu dapat dimaknai juga sebagai rekonsiliasi pasca terjadinya konflik di antara individu dan kelompok masyarakat. Berdasarkan teks Roma bab 5 dan 2 Korintus bab 5, Comblin (dalam Schreiter, 2000, p. 46), berpendapat bahwa rekonsiliasi dapat dibagi dalam tiga level yaitu: Pertama, level Kristologis, Allah mendamaikan manusia dengan diri-Nya melalui Kristus, Kedua, level Ekklesiologis, Kristus mendamaikan orang Yahudi dan bangsa-bangsa lain, Ketiga, level Kosmis, Kristus menda-maikan semua kekuatan di bumi dan di sorga.

Rekonsiliasi pada level pertama dapat juga diartikan sebagai rekonsiliasi vertikal, rekonsiliasi yang terjadi antara manusia dengan Allah, sedangkan pada level kedua sebagai rekonsiliasi horisontal, rekonsiliasi yang terjadi di antara sesama manusia. Sedangkan level ketiga merupakan pengharapan eskatologis yang menjadi puncak rekonsiliasi, dimana seluruh ciptaan Allah didamaikan di dalam Kristus. Dalam perpektif Biblis dan teologis Kristen rekonsiliasi vertikal dan horisontal memiliki keterkaitan yang tak dapat dipisahkan. Pengalaman rekonsiliasi dengan Allah akan membawa manusia kepada rekonsiliasi dengan sesama. 


\section{Rekonsiliasi antara Manusia dengan Allah}

Level pertama dari rekonsiliasi adalah rekonsiliasi vertikal. Dalam rekonsiliasi vertikal, Allah mendamaikan manusia dengan diri-Nya melalui Kristus,

Sebab jika kita, ketika masih seteru telah diperdamaikan oleh Allah melalui kematian AnakNya, lebih-lebih kita yang sekarang telah diperdamaikan, pasti akan diselamatkan oleh hidupNya, dan bukan hanya itu saja. Kita malah bermegah dalam Allah melalui Yesus Kristus Tuhan kita, sebab melalui-Nya kita sekarang telah menerima pendamaian(Rm. 5:10-11).

Semuanya ini dari Allah, yang dengan perantaraan Kristus telah mendamaikan kita dengan diri-Nya, dan yang telah mempercayakan pelayanan pendamaian kepada kami. Sebab Allah mendamaikan dunia dengan diri-Nya oleh Kristus dengan tidak memperhitungkan pelanggaran mereka. Ia telah mempercayakan berita pendamaian itu kepada kami (2 Kor. 5:18-19).

Teks di atas menjelaskan gambaran relasi manusia dengan Allah adalah tentang persahabatan dan permusuhan. Setelah kejatuhan manusia ke dalam dosa maka relasi manusia dengan Allah terputus atau dalam situasi perseteruan. Allah-lah yang mengambil insisiatif untuk terjadinya rekonsiliasi kembali antara Allah dan manusia. Ryrie menjelaskan (1986, p. 37), akibat dosa, maka Allah dan manusia berada dalam hubungan permusuhan dan perseteruan. Allah menganggap manusia sebagai seterunya. Perkataan Paulus dalam Roma 5:9 mendukung tafsiran bahwa seteru-seteru merupakan sasaran murka Allah. Keadaan keterpisahan manusia dengan Allah telah parah sehingga kebutuhan akan adanya pendamaian menjadi sangat penting sekali. Allah-lah yang mengambil insisiatif untuk terjadinya rekonsiliasi kembali antara Allah dan manusia. Rekonsiliasi antara Allah dan manusia terjadi di dalam dan melalui kematian Kristus. Menarik ungkapan yang Paulus katakan, "ketika masih seteru" telah diperdamaikan dengan Allah melalui Kristus. Setelah diperdamaikan bukan saja mengalami keselamatan tetapi juga persekutuan di dalam Kristus. Witmer (dalam Walvoord, 1987, p. 457) menegaskan,
Roma 5: 10 may be rendered 'since', it assume that the reconciliation through the death of His Son is true. In addition, reconciliation was done when we were God's enemeies (lit. 'being enemies'). Since reconciliation was accomplished by Jesus's death, certainly His life is able to insure the complete and final salvation of believers. His life is His present life in which He intercedes (Heb. 7:25) for believers. He died for His enemies, surely He will save those, His former enemies who are now fellowshiping in Him.

Allah sendiri yang mendamaikan manusia dengan diri-Nya, dan itu terjadi melalui Kristus. Dalam rekonsiliasi vertikal, Allah yang menawarkan rekonsiliasi adalah Allah yang juga terlibat dalam perseteruan yang mendalam, sehingga menjadikan-Nya murka. Sebagaimana tertulis dalam teks,

Akan tetapi Allah menunjukkan kasih-Nya kepada kita, oleh karena Kristus telah mati untuk kita, ketika kita masih berdosa. Lebih-lebih, karena kita sekarang telah dibenarkan oleh darahNya, kita pasti akan diselamatkan dari murka Allah. (Rm. 5:8-9).

Dosa manusia menyebabkan kemarahan di pihak Allah, "Allah murka". Tetapi Allah yang murka itu, berkenan datang kepada manusia untuk menawarkan pendamaian (rekonsiliasi) dengan diri-Nya. Kemarahan adalah salah satu unsur penting yang harus diperhatikan dalam sebuah proses untuk mengatasi penderitaan yang disebabkan oleh kekerasan.

Kemarahan adalah salah satu unsur penting yang harus diperhatikan dalam sebuah proses untuk mengatasi penderitaan yang disebabkan oleh kekerasan. Sebagaimana dijelaskan Schreiter (2000, p. 48), kemarahan pada pihak korban merupakan unsur penting, meskipun menyakitkan, dalam usaha mengatasi penderitaan akibat kekerasan. Dalam proses rekonsiliasi seringkali ada ketakutan untuk mengakui atau mengungkapkan kemarahan terhadap tindak kekerasan yang terjadi. Kemarahan harus ditekan agar tidak memancing kekerasan yang lebih besar dari pelaku kekerasan. Hal itu terjadi karena masih takut akan adanya pembalasan dari para penyerang atau karena tampaknya hal itu berarti membalas kekerasan dengan kekerasan. Kemarahan dapat bersifat 
destruktif, tetapi juga harus dipahami bahwa kemarahan adalah suatu pengakuan atas dalamnya penderitaan. Tidak mengungkapkan kemarahan yang timbul akibat kekerasan, sama saja dengan tidak mengakui penderitaan. Dan, tanpa mengakui penderitaan, tidak mungkin membentuk suatu cerita baru kehidupan. Sebagaimana Allah mengungkapkan kemarahan-Nya di dalam kematian Kristus yang menanggung dosa untuk menunjukkan keadilannya. Kemarahan menunjukkan betapa berat penderitaan akibat dari kejahatan itu. Kemarahan yang muncul tidak harus disembunyikan, tetapi dapat diekspresikan, bukan untuk menumbuhkan rasa dendam, melainkan untuk menunjukkan dalamnya penderitaan yang dialami. Pengungkapan penderitaan yang dialami korban dan kerelaan hatinya untuk menawarkan pengampunan, diharapkan akan membawa pelaku ke dalam pertobatan dan rekonsiliasi.

Implikasi penting dari pemahaman bahwa pihak Allah-lah yang lebih dulu menawarkan rekonsiliasi membalikkan satu unsur dari rekonsiliasi yang umumnya diharapkan. Biasanya rekonsiliasi diawali dengan tuntutan agar para pelaku kekerasan bertobat terlebih dahulu, mencari pengampunan dan membaharui dirinya, dengan tidak mengulang kekerasan yang pernah dilakukannya. Dalam perspektif biblis dan teologis Kristen, hal itu justru terbalik, si Korban mengalami pengampunan dan pendamaian dengan Allah terlebih dahulu dan pengalaman itu mendorongnya untuk berdamai dengan sesama manusia. Keterbukaan korban untuk memaafkan diharapkan mendorong si Pelaku untuk bertobat, mengakui kekerasan yang telah dilakukannya dan bertobat dengan tidak mengulang kekerasan yang pernah dilakukannya. Jadi rekonsiliasi dalam perspektif biblis dan teologis Kristen pengalaman pendamaian korban dengan Allah (rekonsiliasi vertikal), menjadi titik awal terjadinya perdamaian dengan si Pelaku (rekonsiliasi horizontal).

\section{Rekonsiliasi Antara Sesama Manusia}

Di atas telah dibahas bahwa dalam perspektif biblis dan teologis Kristen rekonsiliasi horisontal terjadi, bilamana si korban telah terlebih dahulu mengalami rekonsiliasi vertikal dalam kehidupannya. Pengalaman pendamaian dan pengampunan Allah mendorong si korban untuk memberi pemaafan kepada pelaku (oppressor). Selanjutnya keterbukaan hati si korban untuk memaafkan pelaku kekerasan, diharapkan mendorong pelaku untuk mengakui kesalahannya, bertobat dan meminta maaf. Dune (2007) menegaskan, inti tujuan universal Allah sejak kekekalan adalah memulihkan martabat kemanusiaannya dari kejatuhan, menyatukan manusia yang terpisah, dan menyatukan segala sesuatu di dalam Kristus. Rekonsiliasi orang Yahudi dan non-Yahudi di dalam rahmat Allah adalah misteri ilahi yang secara khusus diungkapkan oleh Paulus dalam Efesus pasal 3. Seorang penulis Injili, Budiselić (2012, p. 31) menjelaskan bahwa rencana Allah untuk pemulihan segala sesuatu dimulai dengan individu-individu yang diselamatkan dari kematian rohani, kekuasaan iblis, dan meninggalkan kejahatan serta melakukan perbuatan kasih (Efesus 2: 1-10). Tuhan menyelamatkan individu-individu tetapi rekonsiliasi dan pemulihan juga mencakup hubungan antar pribadi dan antar ras dari semua orang yang menjadi bagian dari Gereja (Efesus 2: 11-22), dan bahwa suatu hari kesatuan akan diciptakan di seluruh alam semesta. Dalam perspektif injili dinyatakan bahwa semua rekonsiliasi baik vertikal maupun horizontal terjadi di dalam Kristus dan melalui pengorbananNya. Pengorbanan Kristus memulihkan manusia dari kejatuhannya, memulihkan kehidupan dan relasi dalam keluarga, memulihkan relasi antar pribadi dan antar suku (Budiselić. 2012, 32-34). Kristus adalah korban yang sekaligus menjadi subyek terjadinya pemulihan yang meliputi, pemulihan manusia dari kejatuhannya, pemulihan kehidupan dan relasi baik antar pribadi, maupun antar suku.

Dilihat dari perspektif ini, maka rekonsiliasi horisontal diprakarsai oleh korban (victims) bukan pelaku. Si korbanlah yang mengawali menjadi subyek dari rekonsiliasi. Para korban terlebih dahulu bersedia untuk memberikan pengampunan kepada si pelaku. Hal ini berbeda dengan proses 
rekonsiliasi yang umumnya diharapkan, dimana biasanya para pelaku yang pertama kali dituntut untuk bertobat dan meminta maaf atas tindakan kekerasan yang dilakukan baru kemudian diberi pengampunan. Rekonsiliasi yang sejati membutuhkan kualitas pengampunan yang jauh lebih kuat dari sekedar tindakan penghukuman. Pentingnya pengampunan dalam proses menuju rekonsiliasi juga dijelaskan

pengampunan (forgiveness) adalah salah satu dari dua kapasitas manusia yang memungkinkan perubahan sosial yang sesungguhnya, sedangkan kapasitas lainnya adalah kemampuan untuk membuat perjanjian yang baru (Shriver, 1995, p. 6).

Pengampunan menjadi strategi penyelesaian berbagai konflik bahkan termasuk didalamnya konflik politik. Pengampunan memungkinkan terjadinya rekonsiliasi dan transformasi sosial yang sejati. Pengampunan memungkinkan terjadinya pemulihan relasi di antara korban dan pelaku dan memutuskan lingkaran dendam dan kekerasan. Pengampunan dalam penyelesaian konflik memungkinkan terbentuknya masyarakat baru dengan perjanjian yang dibaharui setelah melewati masa konflik. Selanjutnya, menurut Shriver, proses pengampunan mesti didahului dengan proses pengungkapan kebenaran dan pengakuan atas kejahatan kemanusiaan yang pernah dilakukan oleh oppressor,

Penggunaan kata pengampunan yang populer kadang-kadang menyiratkan bahwa memaafkan berarti melupakan, meninggalkan perhatian utama pada kejahatan yang dilakukan musuh. Justru sebaliknya: "Ingat dan maafkan" akan menjadi slogan yang lebih akurat (Shriver, 1995, p. 7).

Pengampunan mesti didahului dengan proses remembering, pembongkaran memori tentang kekerasan, kekejaman, ketidakadilan dan luka-luka yang telah terjadi di masa lalu. Pembongkaran terhadap memori masa lalu tersebut untuk dijadikan sebagai sebuah "monumen" bahwa kejahatan kemanusiaan yang pernah terjadi mendapat jaminan tidak akan terulang kembali. Jadi slogan yang lebih tepat bukan "to forgive is to forget", tetapi "remember and forgive".
Remembrance has very strong biblical roots. The idea of remembrance in biblical understanding is always more than just a passive psychological understanding of recalling something back in one's mind. The term 'remember' is often followed by an action, both by God or Israel. The order to remember is a strong theme in the Old and the New Testament, and is used to remember the core of the tradition which is God's saving action towards God's people. In connection with the sin and guilt, God also remembers what happened in the past and when God remembers it is usually connected with consequences. When past wrongs are not remembered anymore, it means that Israel is not being punished any longer and it does not necessarily mean that God does not remember the actual event. The order to remember is lived out by the Israelites. Israel remembers what God has done for them in their life, especially their covenant with the Lord. God commands Israel to teach and remember the knowledge of faith 'when you sit at home and when you walk along the road, when you lie down and when you get up' (Deut. 11:19). The remembrance that Israel is told to practice is to live by the Torah obediently every day(Pakpahan, 2017, pp, 243244).

Mengingat di dalam Alkitab bukan hanya dipahami hanya secara psikologis sebagai memanggil kembali ingatan di dalam pikiran, tetapi sesuatu yang disertai tindakan baik oleh Allah maupun Israel. Tindakan Allah mengingat biasanya berkaitan dengan konsekuensi. Ketika kesalahan masa lalu tidak diingat lagi berarti Israel tidak dihukum lagi. Tetapi hal itu bukan berarti Allah tidak mengingat peristiwa actualnya. Allah mengingat peristiwa aktualnya, tetapi Ia mengampuninya. Israel juga mengingat apa yang Allah telah lakukan untuk hidup mereka, secara khusus perjanjiannya dengan Allah dan perintahNya untuk mengajar anak-anaknya iman kepada Allah.

Pengampunan bukan dengan melupakan, tetapi dengan mengingat (remembering) masa lalu. Hal itubukan untuk melanggengkan lingkaran dendam-medendam, melainkan untuk dijadikan pelajaran bahwa kekerasan yang terjadi di masa lalu tidak boleh terjadi lagi. Hal ini adalah sebuah tindakan untuk memiliki identitas diri (Pakpahan, 2013, p. 
255). Namun, mengingat masa lalu juga berbahaya. Membawa kembali masa lalu yang menyakitkan dapat membawa rasa sakit itu kembali juga. Banyak yang memilih untuk tidak membicarakan cedera masa lalu dan karenanya memilih ide melepaskan masa lalu dengan melupakannya. Hal yang paling menyakitkan biasanya yang dicoba dilupakan karena terlalu menyakitkan untuk diingat. Peringatan juga dapat menyebabkan pembalasan atau bahkan pembalasan. Pengalaman masa lalu yang tidak terselesaikan dapat kembali dan menghantui lagi di masa depan, dan dengan mudah membawa ke tindakan kekerasan lainnya. Banyak kisah kekerasan telah terjadi sebagai akibat dari ingatan yang tidak terselesaikan. Pada tingkat komunal, ingatan akan konflik masa lalu yang sedang ditransmisikan ke generasi berikutnya dapat mengarah pada pembalasan di masa depan. Generasi-generasi itu kemudian berbagi kenangan akan rasa sakit tanpa harus mengalami apa yang sebenarnya terjadi di masa lalu. Dengan memori viktimisasi, suatu hari sekelompok orang dapat memilih untuk membalas dendam terhadap sesuatu yang terjadi pada generasi mereka sebelumnya. Inilah sebabnya mengapa mengingat luka masa lalu adalah hal yang berisiko (Pakpahan, 2017, p.238). Tetapi dalam proses rekonsiliasi mengingat masa lalu merupakan salah satu proses yang sangat penting untuk dilakukan. Dalam menggali ingatan masa lalunya, si korban harus diberi ruang untuk mengekspresikan sepenuh-penuhnya derita yang dialaminya, termasuk rasa marah yang terpendam di dalam hatinya. Menurut Schreiter (2000, p.75), pengisahan kembali narasi para korban adalah hal penting dalam proses rekonsiliasi. Hal ini penting dilakukan untuk mengungkap kebenaran yang tertutup oleh cerita versi pelaku. Para korban kekerasan dan penderitaan mesti menceriterakan kisah hidup mereka berulangkali supaya keluar dari cerita pembohongan. Ketika mereka menceriterakan kembali kisah hidup mereka sendiri, sedikit demi sedikit mereka mulai membangun kisah hidup baru dan benar yang mencakup pengalaman-pengalaman penderitaan dan kekerasan tanpa membiarkan pengalaman-pengalaman tersebut melingkupi mereka. Pada taraf pertama dalam pembentukan cerita benar itu, tercakup usaha membangun semacam peta kekerasan dan penderitaan, yakni dengan membatasinya sedemikian untuk menjinakkan kekuatan jahatnya. Selanjutnya, korban dapat menemukan narasi utama tentang rekonsiliasi ilahi dalam kisah tentang kesengsaraan, kematian dan kebangkitan Kristus. Kisah-kisah tentang penderitaan, tentang pengalaman tindak kekerasan dan pelecehan dapat memperoleh bentuk dan transformasinya di dalam kisah tentang apa yang telah Allah kerjakan di dalam diri Kristus. Kesengsaraan dan kematian-Nya dikisahkan kembali bukan karena kisah itu sungguh keji dan mengandung perlakuan yang sangat tidak adil, melainkan sebagai "kenangan berbahaya" tentang bagaimana Allah menaklukkan kekuasaan yang selama ini digunakan untuk melestarikan ketidakadilan. Kebangkitan Kristus mengokohkan dan menampakkan kuat kuasa Allah atas kejahatan, dan inilah alasannya mengapa boleh membaca kisah-kisah kebangkitan sebagai kisah tentang kuat kuasa penyembuhan serta pengampunan Allah di dalam dunia ini. Lalu melihat misteri Paskah, sebuah lorong dari kesengsaraan kepada kematian dan kemudian kepada kehidupan yang baru, sebagai kisah yang menata kembali pengalaman tindak kekerasan yang kacau balau dan penuh derita menjadi sebuah kisah yang juga akan membawa dari kematian kepada kehidupan.

Kisah kisah tentang kesengsaraan, kematian dan kebangkitan Kristus, memberikan pemahaman tentang apa itu kekuasaan sebenarnya, penderitaan, kematian dan bagaimana kejahatan dikalahkan. Allah melaksanakan rekonsiliasi melalui kematian putra-Nya, Yesus Kristus, dan kebangkitan-Nya menjadi sumber pemulihan dan pembaharuan. Dalam narasi utama tentang rekonsiliasi ilahi inilah si korban menemukan spiritualitas bagi siksa dan derita yang dialaminya. Karena itu, ceritera tentang salib mesti dilihat dalam perspektif solidaritas terhadap orang yang menderita, tertindas dan teraniaya, sebagaimana dijelaskan oleh (Schreiter,2000). Ini tidak boleh dimengerti hanya sebagai suatu tindakan 
sadisme patriakhal tetapi lebih sebagai suatu ungkapan solidaritas yang dalam dengan manusia yang menderita. Tubuh, darah dan salib adalah simbolsimbol yang muncul berulang kali dalam ceritera itu, simbol yang dapat menanggung pertentangan yang terdapat pada inti transformasi penderitaan dan kematian ke dalam pembebasan dan hidup. Kekerasan dalam situasi yang bertemu dengan kejamnya kematian Yesus. Mekarnya kebangkitan menyatakan tempat baru, dimana mereka yang didamaikan berharap menemukan dirinya. Simbol tubuh adalah sarana untuk membangun kembali tubuh yang hancur dari mereka yang menderita dan untuk mempersatukan masyarakat yang terpecah belah, mereka yang dipisah-pisahkan dalam situasi konflik kekerasan dan penindasan. Simbol darah mengandung kenangan akan kekerasan yang perlu disembuhkan dan menyediakan hidup baru bagi mereka yang telah menumpahkan darahnya sendiri. Salib mengungkapkan kebohongan cerita para penindas. Ia menantang pemahaman mengenai apa yang berkuasa di duna ini. Allah menyatakan kuasa-Nya dimana para penguasa dunia ini tidak mengharapkannya. Hal ini terbukti di dalam rekonsiliasi itu sendiri, dimana mereka yang lemah, remuk dan tertindas menunjukkan jalan bagi mereka yang berkuasa. Hal itu pula solidaritas yang didemonstrasikan Kristus di atas kayu salib, ketika Dia masuk dalam kehidupan sang liyan yang menderita. Dan justru solidaritas semacam itu yang menyembuhkan karena hanya Ia yang telah mengalami kepahitan secara penuhyang juga mampu mengatasi semua kepahitan. Allah hadir tidak hanya dalam kesukacitaan semesta tetapi juga dalam kedukacitaan semesta(Wijaya, 2018, p. 175).

Kesengsaraan dan kematian Kristus menjadi simbol solidaritas terhadap kesengsaraan dan penderitaan korban. Dengan mengidentifikasikan narasinarasimereka dalam kesengsaraan, kematian dan kebangkitan-Nya, mereka mentransformasikan pengalaman deritanya menjadi ceritera kehidupan yang baru.Proses selanjutnya dalamremembering adalah pemberian ruang kepada pihak pelaku untuk mengungkapkan situasi-situasi yang melingkupinya yang mendorong keterlibatannya dalam tindakan kekerasan. Seringkali ada alasan tertentu yang menempatkan si pelaku dalam situasi yang dilematis. Karena dalam sebuah konflik terkadang pelaku juga ada dalam situasi dilematis, dimana jika tidak mengambil bagian dalam tindakan kekerasan tersebut keselamatan jiwanya terancam. Karena itu, tujuan pembongkaran terhadap kegelapan sejarah masa lalu adalah untuk melihat bersama sejarah masa lalu (recalling history together) demi menciptakan masa depan yang lebih baik. Dalam proses remembering baik penderitaan si korban, maupun situasi-situasi yang melingkupi si pelaku saat kekerasan terjadi harus diungkapkan. Bidang-bidang ilmu seperti psikologi, sosiologi, dan filosofi mulai condong untuk menyatakan bahwa mengingat adalah cara yang lebih baik untuk menghadapi masa lalu yang menyakitkan daripada melupakannya. Mengingat penting untuk memberi tempat bagi cerita korban dan memberi dia pengakuan atas apa yang terjadi pada dirinya. Tindakan mengingat juga dapat dilakukan dalam level komunal untuk mencari jalan keluar bersama dari trauma masa lalu. Beberapa tindakan mengingat bersama masa lalu yang menyakitkan dalam tingkat nasional telah dilakukan misalnya di Afrika Selatan, Australia, Kanada, dan Israel-Jerman. Meskipun tujuan mengingat tidak pernah sama, hal yang menyakitkan di masa lampau justru diingat untuk dapat lepas dari pengalaman traumatis tersebut (Pakpahan, 2017, p.37). Pengungkapan setiap ingatan baik korban maupun pelaku bukan dimaksud untuk membangkitkan kembali lingkaran kekerasan, melainkan untuk mencapai rekonsiliasi yang benarbenar tuntas. Pembongkaran kebenaran sejarah kekerasan masa lalu ini seringkali menjadi persoalan yang paling berat dalam proses rekonsiliasi.Hal ini disebabkan pengungkapan tindakan kekerasan yang dilakukan oleh pelaku dapat membangkitkan amarah yang memuncak dan tindakan balas dendam dari korban. Karena itu, apapun bentuk rekonsiliasi yang ditawarkan dan bagaimanapun proses selanjutnya yang akan ditempuh, pengampunan mesti menjadi titik awal dari proses rekonsiliasi. Pengampunan 
menjadi jalan untuk memutuskan lingkaran dendam dan kekerasan. Hal ini sesuai dengan pemikiran Desmond Tutu yang menyatakan, bahwa kesediaan korban untuk memberikan pengampunan tidak bergantung kepada pengakuan pelaku kejahatan sebagai pra-syaratnya. Yesus tidak menunggu sampai orangorang yang memaku-Nya di kayu salib memohon pengampunan. Ia siap mengampuni saat mereka menancapkan paku dan berdoa kepada Bapa-Nya untuk mengampuni mereka dan bahkan Dia memberikan kelonggaran atas apa yang tengah mereka perbuat. Jika sang korban baru dapat memaafkan saat pelaku kejahatan mengaku, maka si korban akan terkunci dalam tingkah pelaku kejahatan, terkunci dalam victimhood, apapun sikap dan maksud yang dimilikinya (Tutu, 2001, p. 315).

Jika pengakuan pelaku menjadi pra-syarat bagi pengampunan, si korban akan tetap terpenjara sebagai korban. Memang pengampunan bukan satu hal yang mudah untuk dilakukan. Karena pengampunan berarti melepaskan hak untuk membalas tindakan kekerasan si pelaku dengan tindakan serupa. Pengampunan adalah suatu bentuk kerugian yang membebaskan.Membebaskan korban dari trauma kegelapan masa lalu. Kesediaan si korban untuk memberikan pengampunan menjadi jaminan dipatahkannya spiral kekerasan dan tindakan dendam mendendam. Kesediaan korban untuk memberikan pengampunan dan meninggalkan tindakan balas dendam terhadap pelaku menjadi titik pijak bagi kemungkinan pengungkapan memori masa lalu. Memori masa lalu ini meliputi, tindakan kekerasan yang dilakukan oleh pelaku dan siksaan dan penderitaan yang dialami si korban. Pernyataan tentang kebenaran dan tentang telah melukai seseorang adalah penting guna mencapai akar pelanggaran. Rekonsiliasi tanpa didahului pengungkapan kebenaran, hanya akan membawa kepada sebuah rekonsiliasi yang setengah-setengah dan tidak tuntas. Karena itu, dalam proses rekonsiliasidi antara korban dan pelaku perlu diungkapkan kebenaran narasi mereka, bukan hanya penderitaan si korban, tetapi situasi-situasi yang dialami oleh pelaku sehingga terlibat dalam tindakan kekejaman.Hal ini menjadi mungkin dilakukan, manakala si korban terlebih dahulu membuka hati untuk memberikan pengampunan kepada si pelaku. Proses selanjutnya dalam rekonsiliasi horisontal ini adalah membawa korban dan pelaku dalam proses restorasi. Bahkan menurut Schreiter rekonsiliasi dalam teologi Kristen bukan hanya membawa kepada keadaan sebelum terjadinya konflik, tetapi mengangkatnya ke suatu level yang lebih tinggi yaitu menjadikan korban dan pelaku sebagai manusia baru.

\section{Rekonsiliasi Membawa Korban (Victim) dan Pelaku Kekerasan (Oppresor) Sebagai Komunitas Baru}

Dalam teologi Kristen rekonsiliasi membawa Korban (victim) dan si pelaku (oppresor) ke sebuah tempat, situasi dan relasi yang baru, bahkan menjadikan keduanya menjadi manusia baru. Gambaran komunitas baru ini dapat dilihat dalam persekutuan jemaat mula-mula yang menghindari pembedaan asal-usul keturunan, status atau kedudukan sosial, kemudian mewujudkan persekutuan hidup sebagai manusia baru (Rumbi, 2019, p. 7). The fullness of reconciliation is friendship with God in Jesus Christ, witnessed to in Christ's two-fold command to love God and neighbor (Mat. 22:37-40). Pertama-tama Allah mendamaikan manusia dengan dirinya melalui Kristus. Selanjutnya melalui Kristus juga Allah menyediakan jalan pendamaian bagi perseteruan yang terjadi di antara sesama manusia. "Christ has prepared the way for reconciliation by abolishing the dividing wall of hostility between Jew and Gentile, making of the two one new humanity, establishing peace (Eph. 2:11-18). Teks di atas menyatakan bagaimana Allah membentuk satu masyarakat baru dari bangsa Yahudi dan bangsa lain. Bagaimana Allah mendamaikan dua bangsa yang ada dalam situasi keterasingan dan bermusuhan satu dan yang lain. Beberapa teks dari surat-surat Paulus memperjelas situasi dan keadaan ini,

ingatlah bahwa waktu itu kamu tanpa Kristus, tidak termasuk kewargaan Israel dan tidak men- 
dapat bagian dalam ketentuan-ketentuan yang dijanjikan, tanpa pengharapan dan tanpa Allah di dalam dunia.Tetapi sekarang di dalam Yesus Kristus kamu yang dahulu jauh sudah menjadi dekat oleh darah Kristus. Karena Dialah damai sejahtera kita, yang telah mempersatukan kedua pihak dan telah merobohkan tembok pemisah yaitu permusuhan di antara kita. Dia telah meniadakan hukum Taurat, dengan segala perintah dan ketentuannya, untuk menciptakan keduanya menjadi manusia baru di dalam diri-Nya, dengan itu mengadakan damai sejahtera dan untuk memperdamaikan keduanya, di dalam satu tubuh, dengan Allah oleh salib dengan melenyapkan perseteruan pada salib itu (Efesus 2;12-16).

Dari teks di atas, dapat digali sebuah pemahaman bahwa Allah mendamaikan manusia dengan diriNya di dalam Kristus. Tetapi ada dimensi lain yang tercakup dalam teks tersebut, yaitu rekonsiliasi di antara dua kelompok manusia yang saling terasing dan ada dalam permusuhan.Dalam keadaan tidak didamaikan orang tersebut menjadi orang asing dan berbeda satu sama lain. Schreiter (2000) menjelaskan, dalam keadaan tidak didamaikan seseorang menjadi orang asing dan berbeda satu sama lain, gagasan "asing dan lain" mengingatkan pada salah satu cara utama dalamnya manusia menetapkan batas yang melindungi keamanan dan jati diri mereka. Mereka menjamin keamanan dan jati diri terutama dengan menyingkirkan, menempatkan golongan yang "bukan kita" di seberang batas yang ditetapkan. Mereka itu adalah orang-orang asing dan berbeda. Mereka adalah orang-orang yang dibuat menjadi lain. Ketika sebuah kelompok masih menempatkan kelompok di luar dirinya sebagai "yang lain", maka situasi yang sedemikian sesungguhnya membutuhkan sebuah rekonsiliasi. Apa sebenarnya hakikat yang tersirat dalam kata "yang lain"? Schreiter menyatakan bahwa salah satu cara memaknai kata "yang lain" adalah dengan mendemonisasikannya, "kita dapat mendemonisasikan orang lain, memperlakukannya sebagai seseorang yang harus ditakuti dan disingkirkan jika hal itu mungkin" (Schreiter, 2000, p. 56). Dalam cara memandang demikian, orang lain dilihatsebagai yang kuat dan berbahaya. Karena itu, untuk menciptakan rekonsiliasi diperlukan cara pandang berbeda dalam memandang kelompok di luar, yaitu bukan lagi menggunakan kata 'kami' dan 'mereka' tetapi "kita" sebagai sesama manusia. Sehingga tidak ada lagi alienasi terhadap kelompok yang berbeda dengan dirinya.

Hal lain yang menarik dari teks yang menjelaskan relasi orang Yahudi dan bangsa lain adalah Allah menjadikan kedua kelompok yang saling teralienasi tersebut menjadi "satu manusia baru"(ayat 15). Dalam perspektif baik biblis maupun teologis Kristen, rekonsiliasi bukan hanya penghapusan terhadap penderitaan korban dan pertobatan pelaku tindak kekerasan, tetapi membawa keduanya ke dalam suatu keadaan dan relasi yang baru. Mereka tidak lagi terasing satu dengan yang lain, tetapi menjadi satu komunitas yang baru yaitu komunitas rekonsiliasi. Pemahaman rekonsiliasi dalam teologi Kristen memperlihatkan bahwa korban dan pelaku yang telah mengalami restorasi diangkat ke suatu tempat yang belum pernah ditempati sebelumnya. Jadi bukan hanya membawa kembali ke sebuah situasi sebelum konflik terjadi, tetapi tempat baru yang belum pernah ditinggali dan dialami sebelumnya.

Korban dan pelaku dipanggil untuk menjadi ciptaan baru. Harkat kemanusiaan si korban telah dipulihkan meski mencakup pengalaman tindak kekerasan yang penuh derita. Pengalaman penuh derita yang telah menjadi bagian dari jati diri si korban telah ditransformasikan menjadi sebuah akhir dan babak yang baru. Lingkaran dendam telah dipatahkan, tembok yang memisahkan relasi di antara mereka telah dihancurkan. Mereka kini menjadi sebuah komunitas baru yang telah dipulihkan martabat kemanusiaannya. Dengan demikian relasi di antara mereka kembali disembuhkan dan dipulihkan dan transformasi sosial terjadi. Rekonsiliasi dapat dirajut kembali dan harmoni kembali tercipta.

Dari pemaparan di atas dapat disimpulkan bahwa rekonsiliasi adalah karya Allah melalui Kristus. Rekonsiliasi merupakan rencana agung Allah bagi manusia dan seluruh ciptaan-Nya. Rekonsiliasi diprakarsai oleh Allah dan dinyatakan di dalam Kristus dapat dikatakan sebagai rekonsiliasi holistik 
yang bersifat menyeluruh. Misi rekonsiliasi holistik Allah adalah konteks keseluruhan untuk pekabaran Injil dan pemuridan. Rekonsiliasi dengan Allah adalah esensial dan orang Kristen harus menjadi agen rekonsiliasi. Bagaimanapun, pekabaran Injil tanpa menjadi agen rekonsiliasi holistik mengingkari seluruh kebenaran Injil dan misi Allah. Dari semua gambaran ini, orang Kristen dipanggil untuk setia mengejawantahkan totalitas Misi rekonsiliasi Allah. Melalui kehidupan baru didalam Kristus, kuasa Roh Kudus, setia pada pengajaran gereja, dan melakukan kehidupan praktis kristiani, orang dapat secara mendalam ditransformasikan menuju kehidupan yang mengasihi Allah, sesama dan musuh.

Orang-orang Kristen sebagai agen-agen rekonsiliasi Allah harus masuk mengambil bagian dalam karya rekonsiliasi ini. Misi Gereja tanpa upaya menjadi agen-agen rekonsiliasi Allah secara holistik, sama saja dengan mencederai kebenaran Injil dan totalitas misi rekonsiliasi Allah bagi perdamaian dunia dan seluruh ciptaan-Nya. Orang Kristen dipanggil untuk mengejawantahkan rencana rekonsiliasi Allah melalui kehidupan baru yang diberikan di dalam Kristus, kekuatan Roh Kudus, dan ajaran-ajaran iman Kristen.

\section{Pengharapan Eskatologis Bagi Pembangunan Komunitas Damai Pasca Konflik}

Membangun kembali komunitas damai (rekonsiliatif) pasca konflik adalah sebuah proses yang panjang dan mahal. Perjalanan panjang dan mahal ini, memerlukan pengharapan eskatologis yang menjadi pendorong agar rekonsiliasi tetap bergerak maju, meskipun kadang menghadapi banyak kesulitan. Dalam perspektif biblis dan teologis Kristen pengharapan teologis tersebut adalah keyakinan bahwa pada akhirnya segala sesuatu akan diperdamaikan oleh Allah di dalam Kristus. Thiessen (1979, p.556) menyatakan bahwa damai sejahtera dan kebenaran adalah ciri utama dari pemerintahan kerajaan Kristus di bumi (Yes. 9:5,6). Lebih lanjut dijelaskan oleh Walvoord (1969, p. 272) bahwa pemerintahan Kristus yang bersifat eskatologis dipenuhi dengan kebe- naran dan keadilan (Yes. 11:3-5), serta tiadanya perang dan adanya damai di seluruh dunia (Mzm. 72:7, Yes. 2:4). Namun pengharapan eskatologis tersebut, hendaknya tidak menjadikan orang Kristen berpangku tangan, hanya menantikan saatnya Allah menggenapkan janji pengharapan itu. Rekonsiliasi harus mengarah kepada tindakan yang diejawantahkan dalam strategi. Pengalaman rekonsiliasi bukan melulu peluang untuk berdiam di dalam rahmat Allah yang merangkul segala sesuatu. Rekonsiliasi terarah kepada tindakan. Tindakan itu diejawantahkan dalam berbagai strategi yang mendukung dan menggalakkan proses rekonsiliasi dimaksud.

\section{Proses dan Strategi Membangun Komunitas Damai Pasca Konflik}

Rekonsiliasi tidak boleh menjadi sebuah gagasan yang abstrak. Rekonsiliasi merupakan ihwal menghadapi masa lalu yang dipenuhi dengan konflik, dan memperjuangkan suatu masa depan yang lebih baik. Karena itu, diperlukan sebuah strategi dalam prosesnya. Dalam strategi rekonsiliasi, pembatasan merupakan suatu tahap awal yang penting. Pembatasan yang disarankan sebagai upaya mencapai kadar kesepakatan tertentu yang menyangkut: (1) Apa dan siapa yang membutuhkan rekonsiliasi?; (2) Apakah yang akan menjadi sarana-sarana ampuh untuk mengejawantahkannya?; (3) Seperti apakah keadaan akhir dari rekonsiliasiitu?

Berkenaan dengan persoalan pertama yaitu siapa atau apa yang membutuhkan rekonsiliasi, harus ada konsensus tertentu tentang apa yang memerlukan proses rekonsiliasi itu. Pelaku dan korban umumnya memiliki sudut pandang berbeda. Pelaku biasanya cenderung mengatakan tidak ada yang perlu direkonsiliasi, sedangkan korban akan menunjuk tindakan-tindakan khusus yang perlu diberi perhatian. Sedangkan mengenai sarana-sarana ampuh untuk mengejawantahkan rekonsiliasi, penting dipikirkan sarana yang tepat. Persoalan-persoalan budaya perlu dipertimbangkan, mengimpor proses rekonsiliasi barangkali tidak akan berdaya guna. Akhirnya, harus ada suatu pembahasan yang berkelanjutan mengenai 
seperti apakah keadaan akhir dari proses rekonsiliasi itu. Tentu saja rekonsiliasi membawa pihak-pihak yang terlibat ke suatu tempat yang baru, relasi yang baru. Tetapi proses membayangkan seperti apakah keadaan yang sudah direkonsiliasi itu, tetap perlu diwacanakan terlebih dahulu.

Hal lain yang penting dalam strategi rekonsiliasi adalah perlunya pembedaan antara rekonsiliasi individual dan sosial. Dalam bentuknya yang individual rekonsiliasi itu berlangsung secara internal dalam diri si korban yang bermuara pada konsekuensi sosial dengan mengampuni pelaku kejahatan. Rekonsiliasi sosial merupakan sebuah proses publik yang mengupayakan pertobatan dan pengampunan pada titik-titik utama sepanjang jalan menuju titik akhir yang disebut rekonsiliasi itu. Kedua macam rekonsiliasi tersebut memiliki tujuan-tujuan yang agak berbeda.

Tujuan rekonsiliasi individual pemulihan harkat kemanusiaan yang telah dirusakkan oleh peristiwa-peristiwa traumatis; rekonsiliasi sosial sebuah proses merekonstruksi tatanan moral dari sebuah masyarakat (Schreiter, 2000). Namun demikian, kedua bentuk rekonsiliasi tersebut memiliki beberapa kesamaan diantaranya: 1) Kedua bentuk rekonsiliasi tersebut sama-sama bertalian dengan menghadapi ikhwal masa lampau demi terciptanya masa depan yang lebih baik; 2) Keduanya berupaya menciptakan keadaan agar tindak-tindak kekerasan yang dilakukan di masa lalu tidak akan pernah terulang lagi di masa depan; 3) Keduanya berjuang agar terjadi perubahan dalam relasi, pemulihan harkat kemanusiaan si korban, serta pertobatan dari masyarakat.

Dalam teologi Kristen rekonsiliasi individual dan sosial adalah sesuatu yang saling berkaitan satu dengan yang lain. Pribadi-pribadi yang telah mengalami rekonsiliasi secara personal dapat menjadi agen-agen yang efektif dalam proses rekonsiliasi sosial.Mother Theresa (dalam Mavunduse, 2005, p. 30), menyatakan

perdamaian bukanlah sesuatu yang anda inginkan, perdamaian adalah sesuatu yang harus anda ciptakan, perdamaian adalah sesuatu yang harus anda kerjakan, sesuatu yang menjadi bagian dirimu, sesuatu yang harus anda berikan.

\section{KESIMPULAN}

Sebagaimana telah dipaparkan di atas, baik dalam Perjanjian Lama maupun Perjanjian Baru, perdamaian mencakup baik secara vertikal maupun horizontal. Dalam Perspektif biblis maupun teologis Kristen, membangun perdamaian pasca konflik justru diawali dari pihak si korban (victim) yang telah mengalami rahmat anugerah pengampunan Allah, sehingga ia melangkah untuk memberikan maaf (pengampunan) kepada si pelaku (oppressor). Sebagaimana Yesus tidak menunggu sampai orang-orang yang memaku-Nya di kayu salib memohon pengampunan. Ia siap, saat mereka menancapkan paku, untuk berdoa pada Bapa-Nya untuk mengampuni mereka dan bahkan Dia memberikan kelonggaran atas apa yang tengah mereka perbuat. Jika sang korban baru dapat memaafkan saat pelaku kejahatan menga$\mathrm{ku}$, maka sang korban akan terkunci dalam tindakan si pelaku kejahatan,ia terkunci dalam victimhood. Jika pengakuan si pelaku menjadi pra-syarat bagi pengampunan, si korban akan tetap terpenjara sebagai korban.Karena pengampunan berarti melepaskan hak untuk membalas tindakan kekerasan si pelaku dengan tindakan serupa. Pengampunan adalah suatu bentuk kerugian yang membebaskan. Membebaskan korban dari trauma kegelapan masa lalu. Kesediaan korban untuk memberikan pengampunan menjadi jaminan dipatahkannya spiral kekerasan dan tindakan dendam mendendam. Kesediaan korban untuk memberikan pengampunan dan meninggalkan tindakan balas dendam terhadap pelaku menjadi titik pijak bagi kemungkinan pengungkapan memori masa lalu. Memori masa lalu ini meliputi, tindakan kekerasan yang dilakukan oleh pelaku dan siksaan dan penderitaan yang dialami si korban. Dalam teologi Kristen, rekonsiliasi bukan hanya penghapusan terhadap penderitaan korban dan pertobatan pelaku tindak kekerasan, tetapi membawa keduanya ke dalam suatu keadaan dan relasi yang baru. Mereka tidak lagi terasing satu dengan yang lain, tetapi menjadi satu komunitas yang baru yaitu komunitas damai. Memba- 
ngun kembali komunitas damai (rekonsiliatif) pasca konflik adalah sebuah proses yang panjang dan mahal. Perjalanan panjang dan mahal ini, memerlukan pengharapan eskatologis yang menjadi pendorong agar rekonsiliasi tetap bergerak maju, meskipun

\section{DAFTAR RUJUKAN}

Arjon, Sugit S. 2018. Religious Sentiment in Local Politics. Jurnal Politik, 3 (2): 171-199

Brown, Francis. 1996. The Brown-Driver-Briggs Hebrew and English Lecixon. Peabody: Hendrickson Publishers.

Budiselić, Ervin. 2012. Paul's Understanding of the Church in the Epistle of Ephesians as a Model for Today's Church. KAIROS - Evangelical Journal of Theology, VI (1): 23-47.

Cunningham, Thomas F. 1996. Conflit Resolution Strategies and The Church: The Church 's Role as An Agent of Social Change in the Political Conflict in South Africa. Pretoria: University of South Africa.

Dunn, J. D. G. 2007. "Ephesians,' Barton, John and John Muddiman (ed.): The Oxford Bible Commentary, Oxford: Oxford University Press.

Dami, Z. Anselmus. 2019. Pedagogi Shalom: Analisis Kritis Terhadap Pedagogi Kritis Henry A. Giroux dan Relevansinya Bagi Pendidikan Kristen di Indonesia. Jurnal Filsafat, 29 (1): 134-165, DOI: $10.22146 /$ jf. 42315

Dachi, Zinzendorf. 2018. Menghadirkan Shalom Berdasarkan Yeremia 29:4-7. Illuminate. Jurnal Teologi dan Pendidikan Kristiani. 1 (1): 43-58.

Evan C.F, 1950. "Peace" A Theological Word Book of the Bible.New York, Macimillan.

Klassen, William. Tt. The Forgiving Community. Philadelphia: Westminter Press.

Muqoyyidin, A. Wahyun. 2012. Potret Konflik Bernuansa Agama di Indonesia, "Signifikansi model Resolusi berbasis Teologi Transformatif. Jurnal Analisis, 12 (2):315 kadang menghadapi banyak kesulitan dan tantangan. Dalam perpektif biblis dan teologis Kristen pengharapan eskatologis tersebut adalah keyakinan bahwa pada akhirnya segala sesuatu akan diperdamaikan oleh Allah didalam Kristus.

Mauser, Ulrich. 1992. The Gospel of Peace: A Scriptural Message for Today's World. Louisville, Kentucky:Westminster.

Mavunduse, Diana. 2005. Mengapa Tindak kekerasan? Mengapa Bukan Damai. Maumere: Ledalero.

Pakpahan, B. Jonathan. 2013. Teologi Ingatan sebagai Dasar Rekonsiliasi dalam Konflik. Jurnal Diskursus, 12 (1): 253-277.

Pakpahan, B. Jonathan. 2017. Etika Mengingat Bagi Bangsa Pelupa. Jurnal Ledalero. 16 (2): 3454.

Pakpahan, B. Jonathan. 2017. To Remember Peacefully: A Christian Perspective of Theology of Remembrance as a Basis of Peaceful Remembrance of Negative Memories. International Journal of Public Theology 11 (2): 236-255.

Rumbi, Frans Paillin. 2019. Managemen Konflik Dalam Gereja Mula-Mula: Tafsir Kisah Para Rasul 2:41-47. Evangelikal: Jurnal Teologi Injili dan Pembinaan Warga Jemaat 3 (1): 9-20.

Rad, Gerhard Von. 1964. "Shalom in the Old Testament." In Theological Dictionary of the New Testament. Gerhard Kittel, ed. Grand Rapids: Eerdmans Publishing Company.

Rice, Chris. 2005. Reconciliation as the Mission of God, Christian Witness in a World of Destructive Conflict. Durham: Duke Divinity School, Center for Reconciliation.

Schreiter, Robert J. 2000.Rekonsiliasi Membangun Tatanan Masyarakat Baru. Flores: Nusa Indah. 
2001.Pelayanan Rekonsiliasi, Spiritualitas dan Strategi. Flores: Nusa Indah.

Shriver, Donald W. 1995. An Ethics For Enemies, Forgiveness in Politics. New York: Oxford University Press.

Tutu, Desmond. 2001. Tiada Masa Depan Tanpa Pengampunan. Kartasura: Ciscorre.

Thayer, Joseph H. 1992. Thayer's Greek-english Lexicon of the New Testament. Grand Rapids: Baker Book House.

Takaria, Gerry C. J. 2014. Mengelola Konflik Yang Terjadi Diantara Umat Tuhan. Jurnal Koinonia, 8 (2): 1-15.

Yoder, Perry B. 1987.Shalom, The Bible's Word for Salvation, Justice, and Peace. Kansas: Faith and and Life Press.
Westermann, Clauss. 1992. "Peace (Shalom) in the Old Testament." In The Meaning of Peace: Biblical Studies, Louisville, KY: Westminster.

Wijaya, P. S. 2018. Apakah Aku Penjaga Saudaraku? Mencari Etika ekologis Kristiani yang Panentheistik dan Berkeadilan. Gema Teologika, 3 (2): 167-184. DOI: 10.21460/gema. 2018.32.395

Thiessen, H.C. 1995. Teologi Sistimatika. Malang: Yayasan Penerbit Gandum Mas.

Walvoord, John F. 1969. Yesus Kristus Tuhan Kita. Surabaya: Yakin.

Walvoord, John F. 1987. The Bible of Knowledge Commentary An exposition of Scriptures By Dallas Seminary Faculty, New Testament Edition. Illinois: Victors Book. 